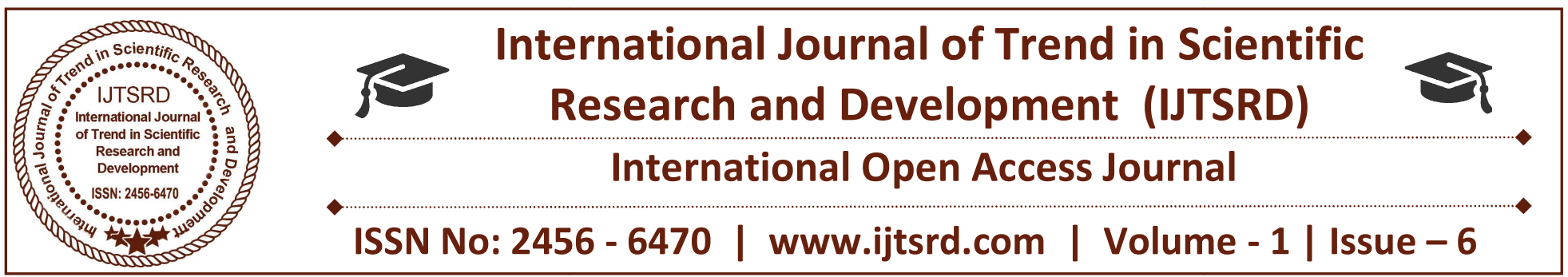

\title{
An Enquiry into the Effect of GST on Real Estate Sector of India
}

\author{
Niraj Dhar Dubey \\ Research Scholar, Department of \\ Commerce, Vinoba Bhave \\ University, Hazaribag, Jharkhand
}

\author{
Dr Devesh Kumar \\ Manager- NF \& ME, Rural \\ Development, Brlps- \\ Jeevika, Patna, Bihar
}

\author{
Sitaram Pandey \\ Assistant Professor, Department of \\ MBA, Cambridge Institute of \\ Technology, Ranchi, Jharkhand
}

\section{ABSTRACT}

GST is one of the revolutionary changes in the indirect taxation system of India since its independence. The main objective behind implementing it is to avoid the duplication of taxes. The focus is on one nation one tax. Further, it aims at increasing the tax base. Real estate sector in India is expected to grow $12 \%$ annually till 2020 . Also, real estate sector is going through structural reforms with the implementation of new acts and norms. The government of India is focusing on affordable housing programs so that it can achieve its target of providing houses to all by 2022. This paper aims to study the impact of GST on real estate sector of India. In addition to that this paper aims at understanding the effect of taxes that were levied earlier and effect of GST on Real Estate in the present scenario.

Keywords: Affordable Housing, GST, Real Estate, Tax Base

\section{Introduction}

GST is considered as one of the revolutionary changes in Indian tax system since 1947. It has changed present scenario of the indirect tax system. One of the basic objectives of GST is to avoid duplication of taxes. Further, it aims at removing the controversial tax revenue sharing system between the centre and state government. It will simplify the process of calculating taxes. Further, it will increase the tax base for collecting indirect taxes. In India, concurrent Dual GST is applicable on goods and services. Almost every sector of the economy has been affected directly or indirectly by the implementation of GST. Real estate sector of India is not the exception further this sector is going through the transitional phase of the implementation of new acts and bodies like RERA (Real Estate Regulatory Authority (2016)), REITs (Real Estate Investment Trusts), InvITs (Infrastructure Investment Trusts). Government is also focused on providing houses to all (urban poor population) by 2022 under affordable housing scheme.

\section{Literature Review}

$>$ Dr. R. Vasanthagopal (2011) studied and stated that adopting GST against current complicated indirect tax system in India will be a great step in booming Indian economy.

$>$ Panda and Ratel (2015) analyzed the impact of GST (Goods and Services Tax) on Indian Tax Scenario. They have detailed brief description of the historical Indian taxation system and its tax structure. Then the need arose for the change in tax structure from earlier to GST model. GST has been discussed in detail in this paper by the authors as the background, silent features and the impact of GST in the present tax scenario in India.

Dani S (2016) A Research Paper on an Impact of Goods and Service Tax (GST) on Indian Economy stated that GST would impact negatively on the real estate market. It would add up to $8 \%$ to the cost of new homes and reduce demand by about $12 \%$ 
Shrikant Paranjape (2017), president of CREDAI Pune Metro, maintains that "The impact of the GST on property prices will be difficult to gauge at this stage because of the lack of clarity on abatement for land value. In a product, where the major raw material is not covered by the GST and the completed unit is also not covered by the GST, the tax input benefit will be hard to calculate or justify. Only the market forces, the ready reckoned rates and time, will decide whether and how much benefit will be passed on by the developers to the purchasers."

\section{Objectives of the Study}

The study has the following objectives:

a) To understand the Basics of GST

b) To explore present condition of real estate sector

c) To analyze the effect of GST on the Indian real estate sector.

\section{Research Methodology}

This paper is a descriptive study based on secondary data of journals, articles, newspapers and magazines. A descriptive type research design is adapted to have more accuracy and analysis of research study in accordance with the objectives of the study. The available secondary data is intensively used for the research study.

\section{Understanding the GST}

The GST Bill was approved in the Lok Sabha on March 29, 2017, with four supplementary Legislations-

a) The Central GST Bill, 2017;

b) The Integrated GST Bill, 2017;

c) The GST (Compensation to States) Bill, a. 2017; and

d) The Union Territory GST Bill, 2017.

The GST Council has recommended a four-tier tax structure $-5,12,18$ and $28 \%$. Also on top of the highest slab to compensate the states against revenue loss for the first five years of GST implementation a cess will be imposed on luxury and demerit goods. The GST will subsume central excise, service tax, VAT and other local levies to create a uniform market i.e. one nation one tax. GST is expected to boost GDP growth by about $2 \%$ and check tax evasions

We need to pay GST on the supply of goods and services. The person who is supplying or providing goods or services is liable to charge GST. GST is applied on goods and services at the place where final consumption occurs. GST paid on the purchase of goods and services can be set off against that payable on the supply of goods or services. The manufacturer or wholesaler or retailer will pay the applicable GST rate and can claim back through tax credit mechanism. But being the last person in the supply chain, the end consumer has to bear this tax and so, in many respects, GST is like a last-point retail tax. GST is going to be collected at the point of Sale.

\section{Benefits of GST Bill Implementation}

Experts have stated that following will be the benefits of GST implementation

$>$ The tax structure will be made simple

$>$ The entire Indian market will be a unified market which may translate into lower business costs. It can facilitate seamless movement of goods across states and reduce the transaction costs of businesses.

> Good for export oriented businesses as it is not applied for goods/services which are exported out of India.

$>$ In the long run, the lower tax burden could translate into lower prices on goods for consumers.

$>$ The Suppliers, manufacturers, wholesalers and retailers are able to recover GST incurred on input costs as tax credits. This reduces the cost of doing business, thus enabling fairer prices for consumers.

$>$ It can bring more transparency and better compliance.

> Number of departments (tax departments) will reduce which in turn may lead to less corruption

$>$ More business entities will come under the tax system thus widening the tax base. This may lead to better and more tax revenue collections.

> Companies which are under unorganized sector will come under tax regime.

\section{Present Condition of Real Estate Sector in India}

The real estate sector is one of the most recognized sectors across the world. In India it is next to agriculture sector i.e. second largest sector in terms of employment generation. The growth rate of this sector is expected at $30 \%$ over next decade. Real estate sector can be categorized into four sub-sectors i.e. housing, retail, hospitality, and commercial. The 
Indian real estate market is expected to touch US\$ 180 billion by 2020. The housing sector alone contributes 5-6 \% to the country's Gross Domestic Product (GDP). In the period FY2008-2020, the market size of this sector is expected to increase at a Compound Annual Growth Rate (CAGR) of $11.2 \%$. Retail, hospitality and commercial real estate are also growing significantly, providing the much-needed infrastructure for India's growing needs.

\section{Recent Development in Indian Real Estate Sector}

Real estate sector of india is witnessing a transitional phase. With the implementation of Real Estate Regulation \& Development Act (RERA), Real Estate Investment Trust (REIT), GST, Benami Transactions
(Prohibition) Amendment Act, Change in Accounting standards IFRS \& Affordable housing project of the government the players of the real estate sector has to formulate their plans and strategies accordingly.

Following are the areas where the sector can feel the affect.

Global capital flow into Indian real estate will increase.

$>$ Developers will revamp their business models

$>$ Affordable housing will have the important place

$>$ More industry consolidation; Mergers \& Acquisition

REIT will be acting as growth Catalyst

\section{Impact of GST on Indian real estate sector:}

\section{Before GST}

To understand the impact of GST first we have to go through the previous charges that were levied on buying $\&$ selling of properties. For this the data of major cities have been taken into consideration

\begin{tabular}{|l|l|l|l|l|l|}
\hline Tax \& Charges & Bengaluru & Mumbai & Pune & Chennai & Gurugram \\
\hline VAT & $4.0 \%$ & $1.0 \%$ & $1.0 \%$ & $2.0 \%$ & $4.0 \%$ \\
\hline Service Tax & $4.5 \%$ & $4.5 \%$ & $4.5 \%$ & $4.5 \%$ & $4.5 \%$ \\
\hline Stamp Duty & $5.7 \%$ & $5.0 \%$ & $5.0 \%$ & $7.0 \%$ & $6.0 \%$ \\
\hline $\begin{array}{l}\text { Registration } \\
\text { Charges }\end{array}$ & $1.0 \%$ & $1.0 \%$ & $1.0 \%$ & $1.0 \%$ & $0.5 \%$ \\
\hline Total Taxation & $15.2 \%$ & $11.5 \%$ & $11.5 \%$ & $14.5 \%$ & $15.0 \%$ \\
\hline
\end{tabular}

\section{Source: Industry, JM Financial}

It is clearly visible that tax and charges lies somewhere in between $11.5 \%$ to $15.5 \%$.

\section{After GST}

Residential buildings which are intended to be sold to the buyers, partly or wholly, will attract $12 \%$ GST. However full input tax credit will be available to the sellers.

For states with non-composite VAT, the transaction value changes marginally from $10-11 \%$ to $12 \%$ under the new tax regime. With input cost credits available.

Earlier states with composite VAT require developers to pay lower VAT rates on the total property value without any input tax benefit or partial benefit. Under this regime, developers pass on the transaction cost VAT (1\%) and service tax (4-5\%) to buyers (total 5$6 \%$ ). Developers get offset for only the input service tax component. In the GST regime, the transaction cost increases to $12 \%$, with input credit available on both, services and material. Property transaction costs will increase by $6 \%$, in case no input credit is passed on by developers. If developers pass on the input credit to buyers, the property price increase could be restricted to $1-2 \%$.

\section{Net Effect: If the developers pass on the credits completely and bring down the base prices, then, Home buyers may marginally get benefit under the GST regime.}

Nevertheless, stamp duty will continue to be applicable, irrespective of whether the property is under-construction or constructed, in the pre-GST and post-GST regime. 
International Journal of Trend in Scientific Research and Development (IJTSRD) ISSN: 2456-6470

GST rates for real estate - Input materials

\begin{tabular}{|l|l|}
\hline Description of goods & Rate \\
\hline Steel & $18 \%$ \\
\hline Cement & $28 \%$ \\
\hline Marble and granite & $28 \%$ \\
\hline $\begin{array}{l}\text { Blocks of marble } \\
\text { and granite }\end{array}$ & $12 \%$ \\
\hline $\begin{array}{l}\text { Sand lime bricks } \\
\text { and fly ash bricks }\end{array}$ & $12 \%$ \\
\hline $\begin{array}{l}\text { Natural sand, } \\
\text { pebbles, gravel }\end{array}$ & $5 \%$ \\
\hline Lifts and elevators & $28 \%$ \\
\hline
\end{tabular}

Source: $\quad B M R, \quad$ https://housing.com/news/gst-realestate-will-impact-home-buyers-industry/

Under the GST regime, many of the construction materials are under the 18 and 28 per cent slab. For example, steel and steel products, are mostly in the 18 per cent segment and cement and prefabricated structural components for building or civil engineering, are in the 28 per cent slab. However, as the input tax credit is available on products utilized for construction, the overall tax incidence is neutralized.

\section{Impact of GST on Home Buyers}

The total tax incidence will increase from 5.5 percent to 12 percent but developers will be able to avail of input credit, on all the goods and services purchased and spent in the construction of the property.

As far the raw materials are concerned the prices of input materials can also be volatile. Cement and steel prices can rise unpredictably. Similarly, sand is always in short supply and not available in the monsoons. So, probably industry may not pass on the entire benefit of the tax credit. Also, stage of completion needs to be checked. If the project is at an advanced stage, where considerable cost has already been incurred before the application of the GST, very little input credit will be available and very less benefit will be passed on. Whereas, more benefits can be passed on if the project is at the initial stage.

\section{Impact of GST on under construction property - Affordable housing}

If GST exemption is extended to affordable housing projects (affordable housing is currently exempted from service tax and a clarification is expected from the government for exemption from GST), then, affordable houses may become cheaper under the GST regime.

\section{Impact of GST on property prices - Luxury segment}

In the case of luxury properties, the basic construction cost may come down a little, but as the input tax credit is limited to 12 per cent only, it will not be able to bring down tax liability to the lowest as taxes are paid on other expenditures also.

\section{Impact of Reverse charge mechanism on construction costs}

In reverse charge mechanism in GST, a registered person has to pay GST on the services and goods that are availed from a person who is not registered under GST. Also, the tax payable under the reverse charge mechanism cannot be adjusted against the input credit available from the GST paid on the inputs but has to be paid by cash/bank payment. Developers are adversely affected under this scheme. They have to pay GST on services availed, like those provided by a person who falls in a non-taxable area. Further, they have to pay GST on the services provided by government or local authorities, like municipalities, etc under this scheme.

This will increase the cost for developers especially the small developers as they were procuring goods and services from unregistered suppliers earlier and for that they had not the same tax liability as in the case now.

\section{Conclusion}

GST can be considered as simple tax system to work with as it has replaced all other prevailing Indirect taxes. This tax system aims at removing every possibility of duplication of taxes. It is expected to be a confidence booster for the industry. It will attract the interest of buyer and investor by bringing more transparency in the taxation system. It will benefit both buyer and seller of the property.

$>$ A seller can take the input credit on the sale of under construction property against the taxes paid by the buyer.

$>$ Earlier, VAT and service tax used to be around 9 $\%$ of the ticket price of the property. Now that will be lower than the GST applied to the sector, the builder will have to pass on the benefit of the price 
reduction to the buyer. The price reduction will be the result of the input tax credits that the builder will avail.

$>$ Earlier builders were charged for Central Excise Duty, VAT and entry taxes collected by the state on construction material costs earlier. Further, they were charged@15\% tax on services like labour, architect fees, approval charges, legal charges etc. However, under the new regime, the changes in construction costs are not such big.

$>$ Reduced cost of logistics will result in reducing expenses as well

The input tax credits will also help in increased profit margins. Overall the GST will be an easier taxation system to work with. Finally, we can conclude that GST along with the present changes in the real estate sector may slow down the pace of growth in the short run but in future, these changes will be beneficial for the growth and consolidation of the sector.

\section{REFERENCES}

1) http://www.thehindu.com/news/cities/chennai/gstand-real-estate/article19185900.ece

2) https://housing.com/news/gst-real-estate-willimpact-home-buyers-industry/

3) https://www.ibef.org/industry/real-estateindia.aspx

4) http://economictimes.indiatimes.com/articleshow/ 57406717.cms?utm_source $=$ contentofinterest\&ut m_medium $=$ text\&utm_campaign $=$ cppst

5) $\mathrm{http}: / /$ indianexpress.com/article/what-is/what-isthe-gst-impact-on-real-estate/

6) R \& Biswas, 2016, "IMPACT OF GST ON INDIAN REAL ESTATE SECTOR”. IJBARR 